\title{
First records of Condylostylus depressus (Aldrich, 1901) and Condylostylus electus (Walker, 1852) (Diptera, Dolichopodidae) in coconut plantations in state of Pará, Brazil
}

\author{
Fernanda V. Penner ${ }^{1 \pm=(\mathbb{D}}$, Yorranna K. R. da Silva ${ }^{1 \mathbb{D}}$, Matheus M. M. Soares ${ }^{\mathbb{D}}$, Lucas F. \\ Bastos $^{3(D)}$, Telma F. V. Batista4 ${ }^{4}$
}

${ }^{1}$ Mestrado Profissional em Uso Sustentável de Recursos Naturais em Regiões Tropicais, Instituto Tecnológico Vale Desenvolvimento Sustentável, Belém, Pará, Brazil. ${ }^{2}$ Programa de Pós-graduação em Entomologia (PPG-Ent) Instituto Nacional de Pesquisas da Amazônia, INPA, Manaus, Amazonas, Brazil. ${ }^{3}$ Sococo Agroindústrias da Amazônia, Brazil. ${ }^{4}$ Laboratório de Proteção de Plantas, Universidade Federal Rural da Amazônia, UFRA, Belém, Pará, Brazil.

拝=-Corresponding author: fernandavpenner@gmail.com

\section{Edited by: Elison F. B. Lima}

Received: February 19, 2021. Accepted: May 02, 2021. Published: June 02, 2021.

\begin{abstract}
We record for the first time two species of Condylostylus Bigot, 1859 from Pará state, Brazil. Condylostylus depressus (Aldrich, 1901) and C. electus (Walker, 1852) were found on commercial crops of Cocos nucifera L., thus pointing to a possible value for biological control. In addition, we provide diagnoses and distributional maps for both species in Brazil.
\end{abstract}

Keywords: long-legged flies, Sciapodinae, predators, biological control.

Dolichopodidae is among the most diverse families within Diptera, containing around 8,000 species in 250 genera that occur in all zoogeographic regions, except the Antarctic (Grichanov 2017). So far, 212 species and 31 genera are known from Brazil (Capellari 2021). Adults are easily recognized by the metallic tegument, slender body, relatively long legs and reduced wing venation (Bickel 2009). Most dolichopodids are predators and frequently occur in large numbers in crop fields. They control populations of slender-bodied insects, including whiteflies, thrips, mites and aphids, considered severe and recurrent pests in Brazilian agriculture (Ulrich 2004; Bickel 2009; Harterreiten-Souza et al. 2020).

Condylostylus Bigot, 1859 currently comprises 260 valid species, from which 78 have been recorded in Brazil (Grichanov 2017; Capellari 2021; Harterreiten-Souza et al. 2020). The genus is distinguished by the following combination of characters: vertical seta inserted in a tubercle, two pairs of well-developed scutellar setae, and $M_{1}$ often sharply recurved basad (Bickel 2009). Species of Condylostylus are abundant and utilized in the biological control of conventional and organic crops in Brazil (see Seffrin et al. 2006; Togni et al. 2010; Harterreiten-Souza et al. 2020).

In this study, we record for the first time Condylostylus depressus (Aldrich, 1901) and Condylostylus electus (Walker, 1852) in the State of Pará, eastern Brazilian Amazon. Both species were collected in crops of Cocos nucifera L., thus indicating a potential value for biological control. Furthermore, we provide diagnoses and distribution maps for both species in Brazil.

Studied specimens were collected with yellow adhesive traps (23×28 $\mathrm{cm}$, mark ISCA) on the Reunidas Farm, located in the municipality of Santa Izabel do Pará $\left(01^{\circ} 13^{\prime} 40.2^{\prime \prime} \mathrm{S} 48^{\circ} 02^{\prime} 54.4^{\prime \prime} \mathrm{W}\right)$ in the experimental area called "J-152". The area is composed by a 19.21 ha, seven-yearold coconut (variety green-dwarf) crop field. Forty traps were installed at the base of plants at $1.50 \mathrm{~m}$ from the soil and were changed every fifteen days during a year (October 2017 to September 2018). The area was selected from a previous study on the economic importance of phytophagous insects conducted by Bastos et al. (2019), where the traps used showed a high incidence of Dolichopodidae family, but due the collection method and preservation, few specimens could be identified at the species level.

Individuals were identified and deposited in the Invertebrate Collection of the National Institute of Amazonian Research (INPA). The identification was later confirmed by Dr. Daniel Bickel, dipterist and researcher of Australian Museum, currently reviewing the genus Condylostylus. Terminology follows mainly Cumming \& Wood (2017). Specimens were photographed with a Leica MC170 HD camera, attached on a Leica M165C stereomicroscope, and the multiple images were stacked and combined using Leica Application Suite V4.11. Distribution map was made using the software Qgis 2.18 .28 based on data from IBGE (2019), Capellari (2021) and Harterreiten-Souza et al. (2020).

\section{Condylostylus depressus (Aldrich, 1901)}

Psilopus depressus Aldrich, 1901: 359. Type locality: Tabasco, Mexico.

(Figs. 1, 2).

Diagnosis (males). Frons with pale hairs next to vertical seta (Fig. 2B). Mesonotum metallic green with weak coopery reflections; five pairs of strong dorsocentral setae, 1 pair of pre- and 1 pair of postsutural acrostichals setae. Legs yellow, except all coxae, hind trochanter, basal $4 / 5$ of fore and mid femora, entirely hind femur, apex of hind tibia, fore and mid tarsus from apex of basitarsus, and entirely hind tarsus brown to dark brown (Fig. 2A). Fore tarsomeres 2-4 with ventral row of short setae (Fig. 2C); mid tarsus unmodified; hind tarsomeres 4-5 dorsoventrally flattened (Fig. 2D). Wing mostly hyaline, with inverted u-shaped macula on apical half (Fig. 2A).

Examined material. Brazil, Pará, Santa Izabel do Pará, Reunidas Farm $01^{\circ} 13^{\prime} 40.2^{\prime \prime} \mathrm{S} 48^{\circ} 02^{\prime} 54.4^{\prime \prime} \mathrm{W}, 09-23 . v .2019$, adhesive trap, Penner \& Silva cols. (1 male). (Fig. 1). 


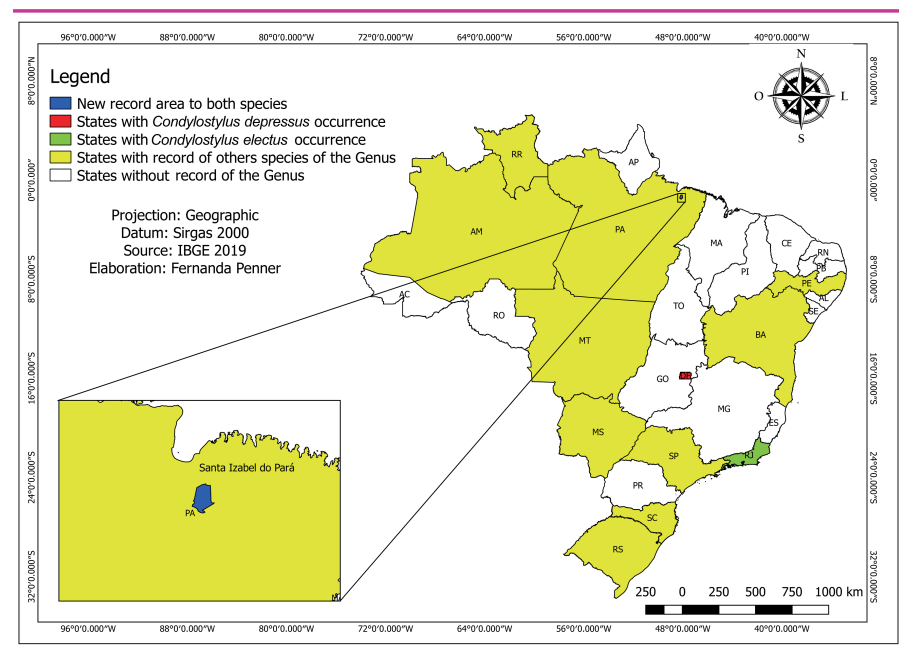

Figure 1. Geographic records, by states, of Condylostylus depressus (Aldrich) and Condylostylus electus (Walker) in Brazil. Source: Author based on data (Capellari 2021; IBGE 2019).

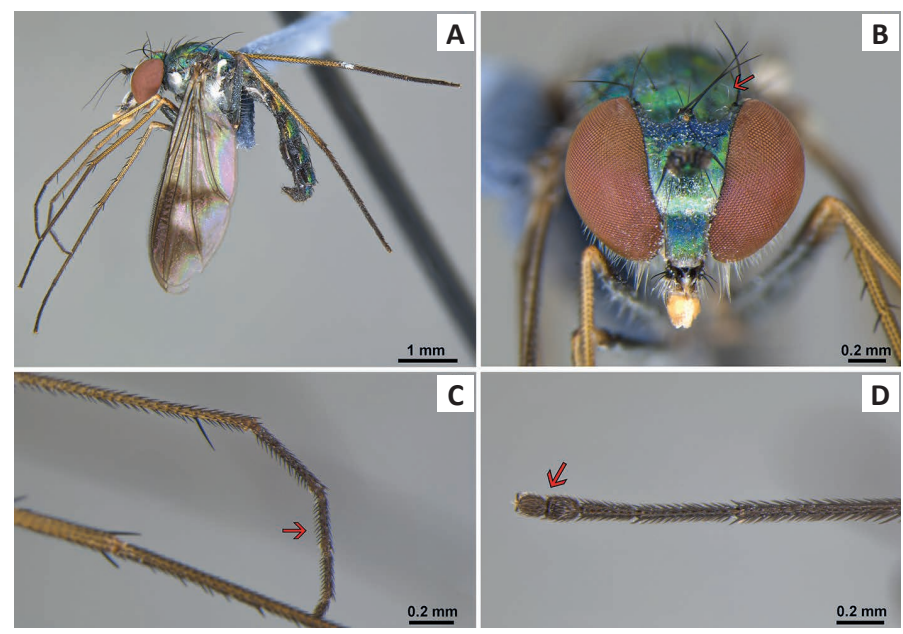

Figure 2. Condylostylus depressus (Aldrich). A. Habitus, lateral view; B. Head frontal view (arrow pointing pale hairs); C. Fore tarsus, anterior view (arrow pointing ventral row of short setae; D. Hind tarsus, dorsal view (arrow pointing flattened tarsomeres).

\section{Condylostylus electus (Walker, 1852)}

Psilopus electus Walker, 1852: 207. Type locality: Brazil, Rio de Janeiro.

(Figs. 1, 3)

Diagnosis (males). Frons with numerous black hairs next to vertical seta (Fig. 3B). Mesonotum metallic dark green, with bluish reflections; five pairs of strong dorsocentral setae, four pairs of acrostichals setae, 1 pre-, 1 sutural and 2 postsutural. Brown to dark brown legs (Fig. $3 \mathrm{~A})$; fore tibia with posteroventral row of setae from basal $2 / 9$ to $7 / 9$ (Fig. 3C); mid tibia with anterior row of setae, longer than diameter of tibia (Fig. 3D); mid basitarsus with anterior row of little round bumps extending to the basal half of mid tarsomere 2 (Fig. 3E); hind tarsus unmodified. Wing mostly brown, with basal $1 / 3$, apex of cells $M_{1}$ and $M_{4}$, a quadrangular portion in cell $r_{4+5}$ beyond vein $\mathrm{dm}-\mathrm{m}$ hyaline (Fig. $3 A)$.

Examined material. Brazil, Pará, Santa Izabel do Pará, Reunidas Farm $01^{\circ} 13^{\prime} 40.2^{\prime \prime} \mathrm{S} 48^{\circ} 02^{\prime}$ 54.4" W, 09-23.v.2019, adhesive trap, Penner \& Silva cols. (2 males).

Distribution. Brazil (states of Rio de Janeiro and Pará) (Fig. 1).

This is only the second occurrence record for $C$. electus and $C$. depressus in Brazil. Previously, C. electus was recorded only from its type locality in the Atlantic Forest, Rio de Janeiro state (Walker 1852) and is here reported for the first time in agricultural landscapes. Condylostylus depressus was recently recorded from the Federal District in Brazil and represents the most abundant species of Condylostylus occurring in agroecosystems (Harterreiten-Souza et al. 2020). Both species are reported for the first time in the Amazon biome.

Several works have demonstrated the importance of Dolichopodidae and Condylostylus in the biological control of pest potentials in crops. Lundgreen et al. (2013) used molecular analysis to identify the main predators of the cassava whitefly (Aleurotrachelus socialis Bondar, 1923) in Colombia and demonstrated the potential as predator of Condylostylus sp. on these insects. The family was the Diptera most abundant in coconut crops in the state of Espírito Santo, southeast Brazil (Comério \& Benassi 2013). Condylostylus was the most abundant genus in Citrus orchards from Vero Beach, Florida, USA, and the individuals were observed displaying predatory activity, thus reinforcing the evidence of their natural enemy role in agroecosystems (Cicero et al. 2017). Harterreiten-Souza et al. (2020) demonstrated that Condylostylus species are more abundant in agricultural crops than in agroecosystems. Further, the same authors recorded 16 species of Condylostylus in greenery crops from Federal District (Midwestern Brazil), which ranked second in abundance among the Dolichopodidae genera.

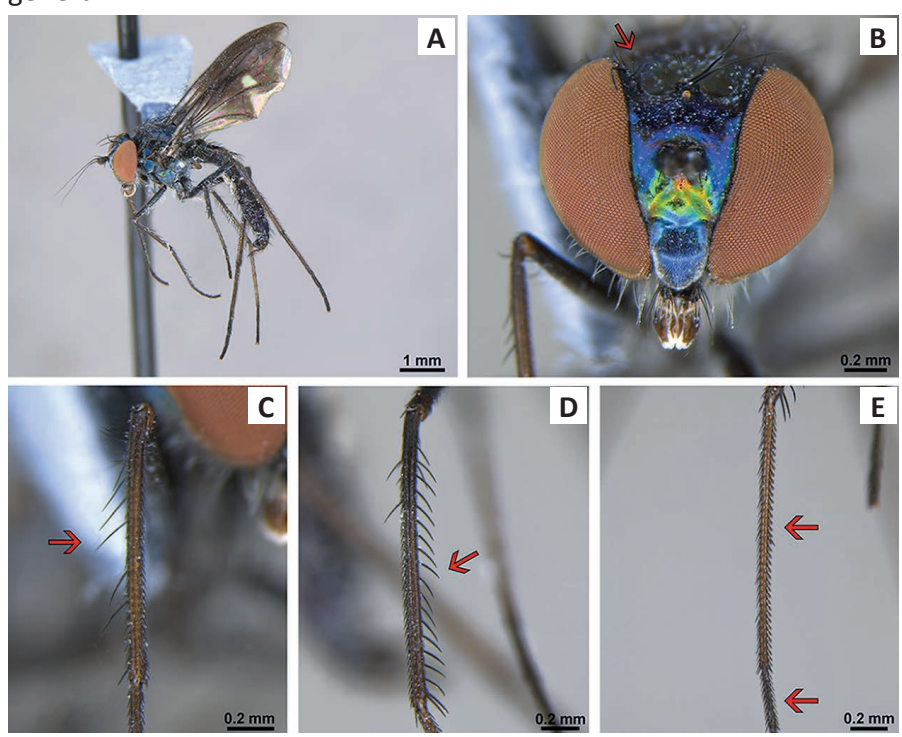

Figure 3. Condylostylus electus (Walker). A. Habitus, lateral view; B. Head frontal view (arrow pointing black hairs); C. Fore tibia, dorsal view (arrow pointing posteroventral row of setae; D. Mid tibia, dorsal view (arrow pointing anterior row of setae); E. Mid tarsomeres 1-2, dorsal view (arrows pointing anterior row of little round bumps).

Data on arthropod colonizing crop fields strengthen the development of integrated pest management, reducing significant financial losses (Weseloh \& Hare 2009). In order to the preservation of natural mortality factors, biological control is frequently recommended for regulating populations of target species. In particular, predators and parasitoids represent the main natural alternatives for pest control in agroecosystems (Spennemann 2019; Dunn et al. 2020).

Studies on the arthropod fauna found in coconut palm are occasionally limited to mentioning the existence of natural enemies, and there are only rare records of the occurrence of their specific predators, whose conservation strategies are essential for keeping pest populations below the level of economic damage, reducing the need for pesticide use.

Despite the increasing number of research on Dolichopodidae from Brazilian agricultural landscapes, information on biology, morphology, ecology and population distribution of Condylostylus in Brazil are still below expectations, ratifying the need for occurrence records in agricultural crops that enable knowledge of species used in biological control against other invertebrates.

\section{Acknowledgments}

We thank the Company Sococo Agroindústrias da Amazônia for financing the study, especially Dr. Paulo Manoel Pontes Lins and the team of technicians in the plant health sector for enabling the partnership with the Universidade Federal Rural da Amazônia and permit the collection of specimens; and Dr. Daniel Bickel from for his 
support in taxonomic identification. MMMS thanks the Coordenação de Aperfeiçoamento de Pessoal de Ensino Superior (CAPES) for the PhD scholarships.

\section{Authors' Contribution}

FVP, YKRS and LFB collected the studied specimens, wrote, and edited the manuscript. MMMS made the diagnosis, and photographs of the species and wrote the manuscript. TFVB coordinated the execution of the project that enabled the collection of specimens. All authors read and approved the final version.

\section{References}

Bastos, L. F.; Santos, A. V. F.; Penner, F. V.; Siqueira, L. M. M.; Silva, A. G.; Martins, I. C. F.; Lins, P. M. P.; Batista, T. F. V. (2019) Spatial Analysis and Population Dynamics of Haplaxius crudus (Hemiptera: Cixiidae) in Coconut Amazon. Journal of Agricultural Science, 11(14): 186197. doi: 10.5539/jas.v11n14p186

Bickel, D. J. (2009) Dolichopodidae (long-legged flies). In: Brown, B. V.; Borkent, A.; Cumming, J. M.; Wood, D. M.; Woodley, N. E.; Zumbado M. A. (Eds.), Manual of Central American Diptera, pp. 671-694. Ottawa: NRC Research Press.

Capellari, R. S. (2021) Dolichopodidae in Catálogo Taxonômico da Fauna do Brasil. PNUD. http://fauna.jbrj.gov.br/fauna/ faunadobrasil/14385. Access on: 14.iv.2021.

Cicero, J. M.; Adair, M. M.; Adair Jr., R. C.; Hunter, W. B.; Avery, P. B.; Mizell, R. F. (2017) Predatory behavior of Long-Legged Flies (Diptera: Dolichopodidae) and their potential negative effects on the parasitoid biological control agent of the Asian Citrus Psyllid (Hemiptera: Liviidae). Florida entomologist, 100(2): 485-487.

Comério, E. F.; Benaci, V. L. R. M. (2013) Dipterofauna em cultura de coqueiro anão verde associada a plantas invasoras em Linhares, ES, Brasil. Entomobrasilis, 6(3): 217-226. doi: 10.12741/ebrasilis. v6i3.346

Cumming, J. M.; Wood, D. M. (2017) Adult morphology and terminology. In: Kirk-Spriggs, A.H.; Sinclair, B.J. (Eds.), Manual of Afrotropical Diptera. Volume 1. Introductory chapters and keys to Diptera families. Suricata 4, pp. 89-113. Pretoria: South African National Biodiversity Institute.

Dunn, L.; Lequerica, T. M.; Reid, C. R.; Latty, T. (2020) Dual ecosystem services of syrphid flies (Diptera: Syrphidae): pollinators and biological control agents. Pest Management Science, 76: 19731979. doi: 10.1002/ps.5807

Grichanov, I. Ya. (2017) Alphabetic list of generic and specific names of predatory flies of the epifamily Dolichopodoidae (Diptera). Second edition. Plant Protection News, Supplements, 23: 1-563. doi: $10.5281 /$ zenodo.884863

Harterreiten-Souza, E. S.; Pujol-Luz, J. R.; Capellari, R. S.; Bickel, D.; Sujii, E. R. (2020) Diversity and spatial distribution of predacious Dolichopodidae (Insecta: Diptera) on organic vegetable fields and adjacent habitats in Brazil, Florida Entomologist, 10(2): 197-205. doi: 10.1653/024.103.0207

IBGE - Instituto Brasileiro de Geografia e Estatística (2019) Malhas Territoriais. Rio de Janeiro: IBGE. https://www.ibge.gov.br/ geociencias/downloads-geociencias.html. Acess on: 15.ix.2020.

Lundgren, J. G.; Lopez-Lavalle L. A. B.; Parsa, S.; Wyckhuys, K. A. G. (2013) Molecular determination of the predator community of a cassava whitefly in Colombia: pest-specific primer development and field validation. Journal of Pest Science, 87: 125-131. doi: 10.1007/s10340-013-0509-7

Seffrin, R. C. A. S.; Costa E. C.; Dequech, S. T. B. (2006) Artropodofauna do solo em sistemas direto e convencional de cultivo de sorgo (Sorghum bicolor (L.) Moench) na região de Santa Maria, RS. Ciência e Agrotecnologia, 30: 597-602. doi: 10.1590/S141370542006000400001

Spennemann, D. H. R. (2019) Introduction of coccinellid beetles to control the coconut scale insect Aspidiotus destructor Signoret in Micronesia 1901-1914. Oriental Insects, 54:197-215. doi:
10.1080/00305316.2019.1604445

Togni, P. H. B.; Cavalcante, K. R.; Langer, L. F.; Gravina, C. S.; Medeiros, M. A.; Pires, C. S. S.; Fontes, E. M. G.; Sujii, E. R. (2010). Conservação de inimigos naturais (Insecta) em tomateiro orgânico. Arquivos do Instituto Biológico, 77: 669-676.

Ulrich, H. (2004) Predation by adult Dolichopodidae (Diptera): a review of literature with an annotated prey-predator list. Studia Dipterologica, 11: 369-403.

Walker, F. (1852) Diptera. In: Saunders, W.W. (Ed.). Insecta Saundersiana: or characters of undescribed insects in the collection of W.W. Saunders, pp. 1-474. London: John Van Voorst.

Weseloh, R. M.; Hare, J. D. (2009) Predation/Predatory Insects. In: Resh, V. H.; Carde, R. T. (Eds.) Encyclopedia of Insects, 2, pp. $837-$ 839. New York: Academic Press. doi: 10.1016/B978-0-12-3741448.00219-8 